\title{
IMPLEMENTASI PENGEMBANGAN PERANGKAT PEMBELAJARAN MATEMATIKA REALISTIK DI SEKOLAH MENENGAH PERTAMA
}

\author{
Utami Murwaningsih, Erika Laras Astutiningtyas, dan Nuryani Tri Rahayu \\ FKIP Universitas Veteran Bangun Nusantara Sukoharjo \\ email: utamimurwaningsih@yahoo.co.id
}

\begin{abstract}
Abstrak: Tujuan penelitian pengembangan ini adalah dihasilkannya perangkat pembelajaran matematika realistik di SMP yang telah tervalidasikan. Metode penelitian dilakukan lewat pengembangan model 4-D (four D model). Subjek uji coba terbatas perangkat pembelajaran adalah siswa kelas VII SMPN 2 Sukoharjo tahun pelajaran 2012/2013. Hasil penelitian berupa produk perangkat pembelajaran pada materi Aljabar di kelas VII SMP. Buku tersebut telah divalidasikan secara teoretis yang dilakukan oleh ahli di bidangnya; rencana pelaksanaan pembelajaran tertentu telah diuji secara terbatas keterbacaan dan disimulasikan;dan perangkat pembelajaran dan instrumen penelitian telah diuji coba terbatas.
\end{abstract}

Kata Kunci: perangkat pembelajaran, matematika realistik

\section{DEVELOPING REALISTIC MATHEMATICS INSTRUCTION KITS IN JUNIOR HIGH SCHOOLS}

\begin{abstract}
This study was aimed to develop validated realistic mathematics instruction kits in junior high schools. The study was carried out using the four-D model. The subjects for the limited try out were the seventh grade students of SMPN 2 Sukoharjo in the academic year of 2012/2013. The product of the study was in the form of instruction kits of Algebra materials for the seventh grade students. The book had been validated theoretically by an expert; the lesson plan had been tried out and simulated; the instruction kits and the research instrument had been tried out.
\end{abstract}

Keyword: instruction kits, realistic mathematics

\section{PENDAHULUAN}

Salah satu ciri penting matematika adalah memiliki objek abstrak sehingga kebanyakan siswa menganggap bahwa matematika itu sulit. Soedjadi (1999:41) mengemukakan bahwa sifat abstrak tersebut merupakan salah satu penyebab sulitnya seorang guru mengajarkan matematika sekolah. Namun, guru harus berusaha mengurangi sifat abstrak tersebut sehingga memudahkan siswa menangkap materi yang diberikan. Guru perlu memahami cara-cara penyampaian materi pelajaran. Di samping penguasaan materi, cara menyajikan atau menyampaikan materi matematika merupakan syarat mutlak yang harus dikuasai seorang guru matematika. Standar proses pembelajaran yang ditetapkan pemerintah melalui Permendiknas No. 41 Tahun 2007, yaitu mendorong siswa dan guru melakukan aktivitas eksplorasi, elaborasi, dan konfirmasi.

Kenyataan yang ada di SMP Negeri 2 Sukoharjo, pembelajaran matematika masih menggunakan pembelajaran secara konvensional, yaitu pembelajaran yang dimulai dari definisi atau teorema, contoh soal, dan dilanjutkan dengan latihan soal penerapan yang berkaitan dengan kehidupan sehari-hari. Dapat dikatakan pembelajaran berpusat pada guru (guru aktif dan siswa pasif). Guru aktif menyampaikan informasi dan siswa pasif menerima. Kesempatan bagi siswa untuk melakukan refleksi dan negosiasi melalui interaksi antara siswa dengan siswa, dan siswa dengan guru kurang dikembangkan. Pembelajaran tersebut tidak memberi kesempatan kepada siswa untuk mengembangkan ide-ide kreatif dan menemukan berbagai alternatif pemecahan masalah. Pada akhirnya, 
siswa hanya menghafal semua rumus atau konsep tanpa memahami maknanya dan tidak mampu menerapkan dalam kehidupan sehari-hari.

Pembelajaran matematika realistik adalah suatu pendekatan pembelajaran matematika yang menggunakan masalah-masalah kontekstual (contextual problems) sebagai langkah awal dalam proses pembelajaran. Siswa diminta mengorganisasikan dan mengidentifikasikan aspek-aspek matematika yang terdapat pada masalah tersebut. Siswa diberi kebebasan untuk mendeskripsikan, menyederhanakan, menginterpretasikan dan menyelesaikan masalah kontekstual tersebut menurut cara mereka sendiri baik secara individu maupun kelompok, berdasarkan pengalaman atau pengetahuan awal yang telah mereka miliki. Kemudian, dengan atau tanpa bantuan guru, siswa diharapkan dapat menggunakan masalah kontekstual tersebut sebagai sumber munculnya konsep atau pengertian-pengertian matematika yang meningkat abstrak (Soedjadi, 2001a:3). Pembelajaran lewat pendekatan pembelajaran matematika realistik (PMR) diharapkan mengubah aktivitas pembelajaran sehingga tidak lagi terpusat kepada guru, tetapi kepada siswa, bahkan terpusat pada pemecahan masalah kontekstual. Guru berfungsi sebagai pembimbing dalam menyeleksi dan mengarahkan berbagai konstribusi siswa melalui pemecahan masalah kontekstual yang diberikan di awal pembelajaran. PMR akan lebih mengakrabkan matematika dengan lingkungan siswa. Melalui pengaitan konsepkonsep matematika dengan pengalaman siswa sehari-hari, menyebabkan siswa tidak mudah lupa terhadap konsep-konsep/prinsip-prinsip matematika yang ia pelajari. Bahkan, ia juga akan lebih mudah mengaplikasikan konsep atau prinsip matematika tersebut, untuk menyelesaikan soal maupun untuk menyelesaikan permasalahan hidup sehari-hari.

Marpaung (2001:4-5) mengemukakan bahwa PMR memiliki prospek lebih berhasil untuk diterapkan di Indonesia dibandingkan dengan pendekatan-pendekatan lainnya, seperti pendekatan strukturalistik, empiristik dan mekanistik. Hal itu disebabkan pendekatan strukturalistik bagi siswa terlalu abstrak sehingga sangat sedikit siswa yang mampu memahami struktur itu. Pendekatan empiristik, lebih mudah diterima siswa, tetapi kurang berarti dalam kemampuan matematis, sebab kurang memuat komponen matematika vertikal. Pendekatan mekanistik boleh dikatakan tidak ada maknanya dilihat dari sudut matematika, karena kurang menanamkan pengertian. Dipihak lain, PMR bertolak dari masalah-masalah yang kontekstual, siswa aktif, guru berperan sebagai fasilitator, anak bebas mengeluarkan idenya, siswa sharing ide-ide. Artinya, mereka bebas mengomunikasikan ide-ide. Guru membantu membandingkan ide-ide dan membimbing untuk mengambil keputusan tentang ide mana yang lebih baik. Dalam PMR, pembelajaran tidak dimulai dari definisi, teorema atau sifat-sifat, kemudian dilanjutkan dengan contoh-contoh, seperti yang selama ini dilaksanakan di berbagai sekolah. Namun, sifat-sifat definisi dan teorema itu diharapkan seolah-olah ditemukan kembali oleh siswa melalui penyelesaian masalah kontekstual yang diberikan guru di awal pembelajaran. PMR mendorong siswa untuk aktif bekerja, bahkan diharapkan dapat mengkonstruksi sendiri pengetahuan yang diperoleh.

De Lange (1987:72) mengatakan bahwa proses tersebut merupakan proses "conceptual mathematizing" atau matematisasi konseptual, yang dapat digambarkan seperti pada Gambar 1.

Berdasar uraian di atas, pembelajaran matematika perlu diarahkan pada aktivitasaktivitas yang mendorong siswa untuk belajar secara aktif baik mental, fisik maupun sosial. Salah satu upaya yang perlu dilakukan adalah dengan mengaitkan konsep-konsep matematika dengan pengalaman siswa dalam kehidupan sehari-hari. Salah satu pendekatan pembelajaran yang berorientasi pada pembelajaran siswa aktif dan penerapan matematika dalam kehidupan sehari-hari adalah pendekatan PMR terebut. 


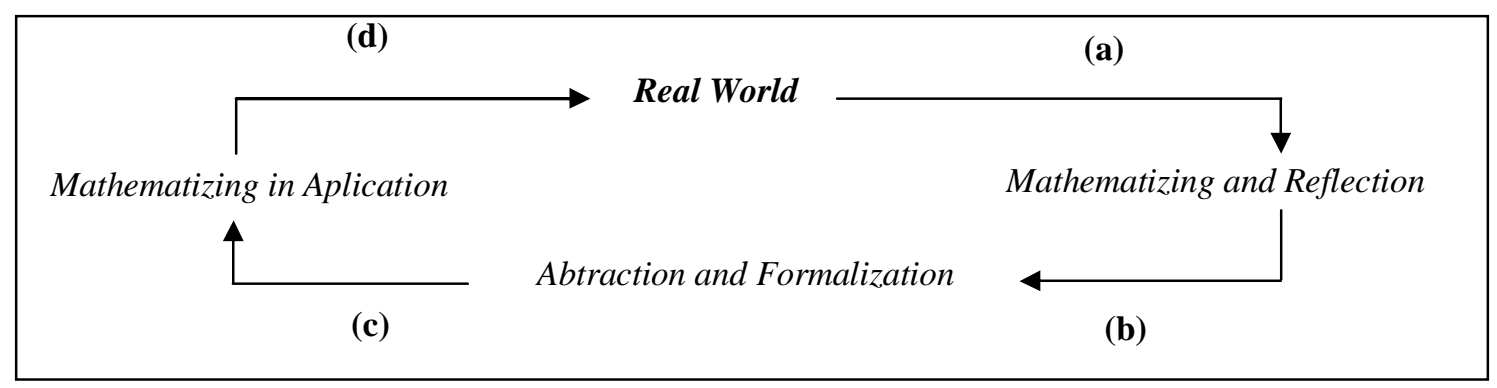

Gambar 1. Matematisasi Konseptual (Conceptual Mathematizing)

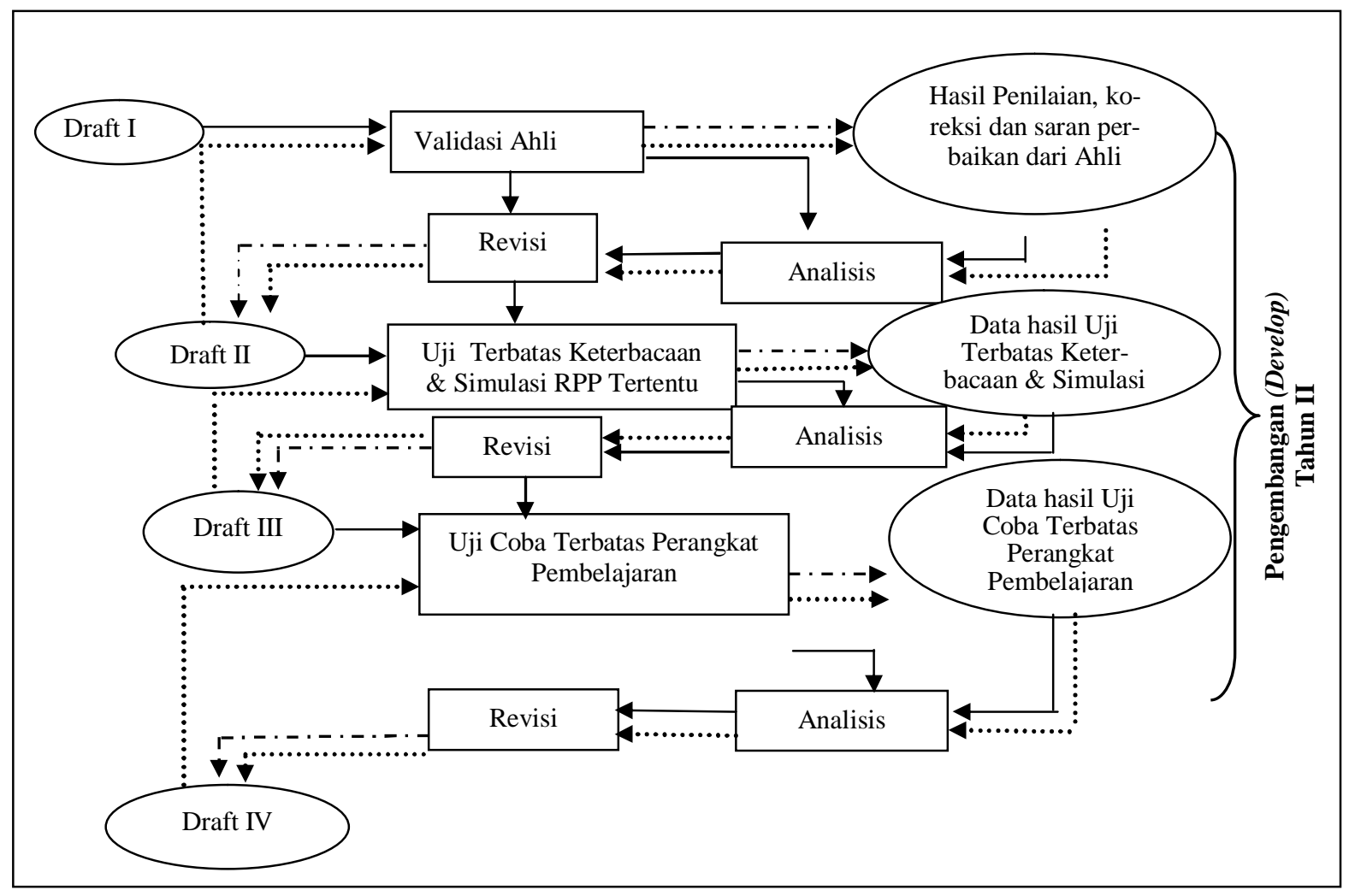

Gambar 2. Modifikasi Model Pengembangan Perangkat Pembelajaran dari Model 4-D

(Four D Model)

Keterangan:

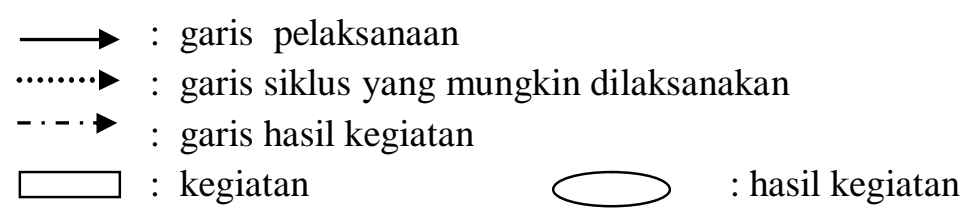

Tahun II : (draf IV/ draf I yang telah direvisi) perangkat pembelajaran dengan pendekatan pembelajaran matematika realistik di Sekolah Menengah Pertama yang telah di uji coba terbatas

Penelitian pengembangan perangkat pembelajaran dengan pendekatan Pembelajaran Matematika Realistik yang telah dilaksanakan peneliti pada tahun pertama, telah menghasilkan: (1) penetapan dan pendefinisian segala sesuatu yang diperlukan dalam pembelajaran, dengan menganalisis tujuan dan batasan materi pelajaran; (2) perancangan perangkat pembelajaran sehingga diperoleh prototipe perangkat pembelajaran contoh yang meliputi

- penyusunan tes beracuan patokan;

- pemilihan media;

- pemilihan format; dan

- perancangan awal bahan ajar matematika 
dengan pendekatan Pembelajaran Matematika Realistik yang meliputi: (1) rencana pelaksanaan pembelajaran; (2) buku siswa; (3) lembar kerja siswa; (4) buku petunjuk guru; dan (5) perangkat tes hasil belajar siswa, pada materi Aljabar di kelas VII SMP.

\section{METODE}

Penelitian ini tergolong penelitian pengembangan, yaitu pengembangan perangkat pembelajaran matematika realistik, meliputi: (1) Rencana Pelaksanaan Pembelajaran; (2) Buku Siswa; (3) Lembar Kerja Siswa; (4) Buku Petunjuk Guru; dan (5) Perangkat Tes Hasil Belajar Siswa, pada materi Aljabar di kelas VII SMP. Bersamaan dengan itu dikembangkan pula instrumen penelitian berupa: (1) Lembar Penilaian Validator terhadap Perangkat Pembelajaran dan Instrumen Penelitian; (2) Lembar Observasi Kemampuan Guru Mengelola Pembelajaran; (3) Lembar Observasi Aktivitas Siswa Selama Mengikuti Proses Pembelajaran; (4) Lembar Angket Respon Guru terhadap Perangkat dan Pelaksanaan Pembelajaran; dan (5) Lembar Angket Respon Siswa terhadap Perangkat dan Pelaksanaan Pembelajaran.

Model pengembangan yang digunakan adalah dengan memodifikasi model 4-D (Four $D$ model) dari Thiagarajan, Semmel dan Semmel (1974: 5-9). Prosedur pengembangan perangkat pembelajaran terdiri dari tiga tahap, yaitu: (1) pendefinisian (define); (2) perancangan (design); (3) pengembangan (develop); dan (4) penyebaran (desseminate), sebagaimana terlihat pada Gambar 2.

\section{HASIL DAN PEMBAHASAN}

Semua perangkat pembelajaran dan instrumen penelitian yang telah disusun dalam bentuk draft I selanjutnya dilakukan penilaian oleh ahli (validator). Hasil validasi yang sudah dilakukan dapat dilihat pada Tabel 1 dan 2 .

Pada umumnya, para validator memberikan catatan dan saran perbaikan RPP ini pada komponen: (1) alokasi waktu; (2) apersepsi dan motivasi; (3) pengkodean $\mathrm{SK}, \mathrm{KD}$; dan indikator (4) perkiraan waktu untuk setiap kegiatan; dan (5) beberapa kesalahan penulisan/ejaan. Namun demikian, revisi terhadap RPP pada tahap ini hanya peneliti lakukan terhadap: apersepsi dan motivasi, pengkodean SK, KD, dan indikator dan kesalahan penulisan/ejaan. Untuk revisi terhadap alokasi waktu dan perkiraan waktu akan peneliti lakukan setelah pelaksanaan uji keterbacaan dan simulasi RPP tertentu.

Secara umum, para validator memberikan saran perbaikan Buku Siswa ini pada komponen: (1) Penomoran; (2) Beberapa kesalahan hitung; dan (3) kesalahan penulisan/ejaan.

Tabel 1. Hasil Penilaian Umum Validator terhadap Perangkat Pembelajaran

\begin{tabular}{llr|r|r|c}
\hline \multirow{2}{*}{ No. } & \multicolumn{1}{c}{ Perangkat yang Dinilai } & \multicolumn{3}{c}{ Banyak Validator Pemberi Nilai } \\
\cline { 3 - 6 } & & 1 & 2 & 3 & 4 \\
\hline 1. & Buku Siswa (BS) & 0 & 0 & 5 & 1 \\
2. & Lembar Kerja Siswa (LKS) & 0 & 0 & 0 & 6 \\
3. & Rencana Pelaksanaan Pembelajaran (RPP) & 0 & 0 & 6 & 0 \\
4. & Buku Petunjuk Guru (BPG) & 0 & 0 & 3 & 3 \\
5. & Perangkat Tes Hasil Belajar Siswa (Kisi-kisi, Lembaran Soal, Alternatif & 0 & 0 & 6 & 0 \\
& Jawaban dan Pedoman Pemberian Skor) & & & & \\
\hline
\end{tabular}

Keterangan nilai:

1: Sangat tidak baik, sehingga belum dapat dipakai, masih memerlukan konsultasi

2: Tidak baik, tetapi dapat dipakai dengan banyak revisi

3: Baik, sehingga dapat dipakai tetapi dengan sedikit revisi

4: Sangat baik, sehingga dapat dipakai tanpa revisi 
Tabel 2. Hasil Penilaian Umum Validator terhadap Instrumen Penelitian

\begin{tabular}{|c|c|c|c|c|c|}
\hline \multirow{2}{*}{ No. } & \multirow{2}{*}{ Instrumen Yang Dinilai } & \multicolumn{4}{|c|}{ Banyak Validator Memberi Nilai } \\
\hline & & 1 & 2 & 3 & 4 \\
\hline 1. & Lembar Observasi Kemampuan Guru Mengelola Pembelajaran & 0 & 0 & 5 & 1 \\
\hline 2. & Lembar Observasi Aktivitas Siswa & 0 & 0 & 4 & 2 \\
\hline 3. & $\begin{array}{l}\text { Lembar Angket Respon Guru terhadap Perangkat dan } \\
\text { Pelaksanaan Pembelajaran }\end{array}$ & 0 & 0 & 2 & 4 \\
\hline 4. & $\begin{array}{l}\text { Lembar Angket Respon Siswa terhadap Perangkat dan } \\
\text { Pelaksanaan Pembelajaran }\end{array}$ & 0 & 0 & 2 & 4 \\
\hline 5. & $\begin{array}{l}\text { Lembar Penilaian Validator terhadap Perangkat dan Instrumen } \\
\text { Penelitian }\end{array}$ & 0 & 0 & 1 & 5 \\
\hline
\end{tabular}

Keterangan nilai:

1 : Sangat tidak baik, sehingga belum dapat dipakai, masih memerlukan konsultasi

2 : Tidak baik, tetapi dapat dipakai dengan banyak revisi

3 : Baik, sehingga dapat dipakai tetapi dengan sedikit revisi

4 : Sangat baik, sehingga dapat dipakai tanpa revisi

Secara umum LKS dinilai baik oleh sangat baik oleh validator sehingga bisa digunakan tanpa revisi. Validator menilai penampilan LKS menarik, mudah dipahami, dan telah sesuai dengan langkah-langkah pendekatan pembelajaran matematika realistik. Tetapi, ada sedikit revisi di penulisan tanda seru (!) pada perintah soal. Sesuai saran validator, tanda seru (!) tersebut dihilangkan sehingga tidak rancu antara tanda seru atau simbol faktorial (!) yang ada di matematika. Pada LKS ini sebagian besar soal untuk kegiatan siswa telah diberikan petunjuk yang mendetail. Siswa dituntun langkah demi langkah dalam menyelesaikan permasalahan.hal ini membuat siswa malas dalam berpikir dan cenderung membatasi kreativitasnya. Sebaiknya, proporsi soal yang diberi petunjuk langkah demi langkah dikurangi, sedangkan soal yang tanpa ditertai petunjuk langkah-langkah pengerjaan ditambah. Hal ini akan menuntut siswa berpikir secara kritis.

Untuk LKS masalah ke-3 (perkalian bentuk aljabar) diberi soal yang berkaitan dengan perkalian suatu bilangan dengan suku dua dan perkalian suku dua dengan suku dua sehingga siswa mendapatkan suatu pola $\mathrm{a}(\mathrm{b}+\mathrm{c})=\mathrm{ab}+\mathrm{ac}$, $(a+b)(a+b)=(a+b)^{2}=a^{2}+2 a b+b^{2}$ yang nanti di kelas VIII digunakan.

Koreksi, saran dan masukan para validator terhadap buku petunjuk guru umumnya berupa: (1) pencantuman alokasi waktu dan tuju- an, dan (2) materi dan perintah soal diperjelas. Koreksi, saran dan masukan para validator terhadap perangkat tes hasil belajar umumnya berupa: (1) kesesuaian penulisan butir soal dengan indikatornya; (2) pengurutan soal; dan (3) koreksi terhadap kesalahan penulisan pada beberapa soal, alternatif jawaban dan pedoman pemberian skor

Revisi terhadap instrumen penelitian pada tahap ini hanya peneliti lakukan dengan membetulkan beberapa kesalahan penulisan/pengetikan/ejaan pada beberapa instrumen penelitian sesuai dengan koreksi, saran dan masukan dari beberapa validator.

Setelah semua perangkat pembelajaran dan instrumen penelitian draft I tersebut direvisi menjadi dratf II, selanjutnya dilakukan uji keterbacaan dan simulasi RPP tertentu. Tujuan kegiatan uji keterbacaan dan simulasi RPP tertentu ini adalah untuk memperoleh masukan apakah semua perangkat pembelajaran dan instrumen penelitian dapat jelas dibaca dan dipahami serta dapat dilaksanakan di lapangan. Berikut dipaparkan pelaksanaan dan hasil dari kegiatan tersebut. Idealnya semua RPP dapat diujicobakan pada kegiatan ini. Namun, karena keterbatasan waktu, sehingga hanya dua RPP, yaitu RPP I dan RP II yang sempat diujicobakan. Kegiatan ini telah dilaksanakan selama tiga hari dengan kegiatan sebagaimana ditunjukkan pada Tabel 4. 
Tabel 4. Kegiatan Uji Keterbacaan dan Simulasi RPP Tertentu

\begin{tabular}{ll}
\hline \multicolumn{1}{c}{ Jenis } & \multicolumn{1}{c}{ Keterangan } \\
Kegiatan & \\
\hline Uji & a. Semua siswa yang menjadi subjek \\
keterbacaan & uji keterbacaan diminta membaca \\
& semua kalimat yang terdapat pada: \\
& Buku Siswa, LKS, Lembar Soal \\
& Tes dan Lembar Angket Respon \\
& Siswa, kemudian menanyakan kali- \\
& mat-kalimat yang kurang dipahami. \\
& b. Calon pengamat dan guru mitra \\
& diminta membaca semua kalimat \\
& pada perangkat pembelajaran dan \\
& instrumen penelitian, kemudian me- \\
& nanyakan kalimat-kalimat yang ku- \\
& rang mereka pahami.
\end{tabular}

Simulasi Selama pelaksanaan simulasi peneliti RPP I bertindak sebagai guru (pengajar), Simulasi calon guru mitra dan calon pengamat RPP II mengamati dan mengecek kesesuaian perkiraan waktu yang tercantum pada RPP dan LKS dengan pelaksanaan simulasi.

Hasil Uji keterbacaan seperti berikut. (1) Semua siswa yang menjadi subjek uji keterbacaan menyatakan dapat memahami kalimatkalimat yang terdapat pada Buku Siswa, LKS, Lembar Tes Hasil Belajar Siswa dan Lembar Angket Respon Siswa. (2) Calon pengamat dan guru mitra menyatakan dapat memahami maksud semua kalimat yang terdapat pada semua perangkat pembelajaran dan instrumen penelitian. Berdasarkan paparan hasil uji keterbacaan, diputuskan untuk tidak melakukan revisi terhadap semua perangkat pembelajaran dan instrumen penelitian draft II, tetapi langsung menggunakannya pada kegiatan simulasi RPP tertentu pada hari berikutnya.

Semua data hasil pelaksanaan simulasi RPP I dan RPP II tersebut digunakan sebagai bahan diskusi dengan calon pengamat dan guru mitra untuk merevisi perangkat pembelajaran dan instrumen penelitian draft II menjadi draft III. Berdasarkan hasil diskusi, diperoleh masukan (data) sebagai berikut. (1) Mata pelajaran matematika untuk satu kali tatap muka adalah dua jam pelajaran ( 2 x 40 menit). (2) Materi itu diajarkan dengan alokasi waktu 15 jam pelajaran dan untuk setiap KD diajarkan selama tiga jam pelajaran.

Berdasarkan paparan data hasil uji keterbacaan dan simulasi RPP I, RPP II serta hasil diskusi dengan calon pengamat dan guru mitra di atas, diputuskan untuk melakukan revisi terhadap semua perkiraan waktu untuk beberapa kegiatan pada semua RPP, perkiraan waktu pada semua LKS, Buku Siswa, dan instrumen Lembar Observasi Aktivitas Siswa.

Uji coba perangkat pembelajaran di lapangan bertujuan untuk memperoleh data atau masukan dari guru, siswa dan para pengamat (observer) terhadap semua perangkat pembelajaran serta untuk mengetahui reliabelitas instrumen lembar observasi, sebagai dasar untuk melakukan revisi (penyempurnaan) draft III menjadi draft IV (draft final). Siswa yang menjadi subjek uji coba perangkat ini adalah siswa kelas VIIA SMPN 2 Sukoharjo sebanyak 36 siswa dengan kemampuan akademik yang beragam (ada siswa yang berkemampuan tinggi, sedang, dan rendah) dengan tiga orang guru mitra dan pengamat.

Rancangan yang akan digunakan dalam uji coba perangkat pembelajaran adalah twogroup design. Sampel pertama sebagai kelas eksperimen yang dikenai perangkat pembelajaran dengan pendekatan Pembelajaran Matematika Realistik,yaitu kelas VII G, sedangkan sampel kedua sebagai kelas kontrol yang menggunakan perangkat pembelajaran konvensional, yaitu kelas VII H. Sebelum dikenai perlakuan, dilakukan uji keseimbangan dengan t-test sampel independen. Setelah diketahui data tersebut homogenitas dan normal, langkah selanjutnya adalah menghitung data dengan rumus t-test yang ditunjukkan pada Tabel 5 .

Kesimpulan yang dapat diambil adalah sebagai berikut. (1) Ada perbedaan rerata yang signifikan antara kelas eksperimen dan kelas kontrol pada materi aritmatika sosial. Untuk mengetahui prestasi belajar siswa manakah yang lebih baik, maka dibandingkan rerata marginal dari kedua populasi (karena hanya terdapat 2 populasi saja). Rerata untuk kelas eksperimen adalah 78,056 sedangkan rerata 
kelas kontrol adalah 68,778 sehingga prestasi belajar matematika siswa pada kelas eksperimen lebih baik daripada prestasi belajar siswa pada kelas kontol. Dengan kata lain, prestasi belajar matematika siswa yang dikenai pembelajaran dengan pendekatan matematika realistik lebih baik daripada prestasi belajar matematika siswa yang dikenai pembelajaran konvensional bagi siswa kelas VII SMP Negeri 02 Sukoharjo pada materi aritmatika sosial. (2) Ada perbedaan rerata yang signifikan antara kelas eksperimen dan kelas kontrol pada materi perbandingan. Rerata untuk kelas eksperimen adalah 73,611111 sedangkan rerata kelas kontrol adalah 58,111111 sehingga prestasi belajar matematika siswa pada kelas eksperimen lebih baik daripada prestasi belajar siswa pada kelas kontol. Dengan kata lain, prestasi belajar matematika siswa yang dikenai pembelajaran dengan pendekatan matematika realistik lebih baik daripada prestasi belajar matematika siswa yang dikenai pembelajaran konvensional bagi siswa kelas VII SMP Negeri 02 Sukoharjo pada materi Perbandingan. (3) Ada perbedaan rerata yang signifikan antara kelas eksperimen dan kelas kontrol pada materi himpunan. Rerata untuk kelas eksperimen adalah 76,777778, sedangkan rerata kelas kontrol adalah 71,055556 sehingga prestasi belajar matematika siswa pada kelas eksperimen lebih baik daripada prestasi belajar siswa pada kelas kontol. Dengan kata lain, prestasi belajar matematika siswa yang dikenai pembelajaran dengan pendekatan matematika realistik lebih baik daripada prestasi belajar matematika siswa yang dikenai pembelajaran dengan pendekatan langsung pada materi himpunan.

Sebagaimana disebutkan sebelumnya bahwa sebelum dilakukan analisis untuk merevisi perangkat pembelajaran, terlebih dulu perlu dilakukan analisis reliabilitas instrumen lembar observasi kemampuan guru mengelola pembelajaran dan lembar observasi aktivitas siswa selama mengikuti proses pembelajaran. Berikut ini dipaparkan hasil analisis reliabilitas instrumen lembar observasi dan analisis untuk merevisi perangkat pembelajaran dari draft III menjadi draft IV (draft final).

Hasil analisis reliabilitas lembar observasi kemampuan guru mengelola pembelajaran dan lembar observasi aktivitas siswa selama mengikuti proses pembelajaran ini dapat dilihat pada Tabel 6 dan Tabel 7.

Tabel 5. Hasil Uji Coba Perangkat Pembelajaran dengan Pendekatan PembelajaranMatematika Realistik terhadap Prestasi Belajar

\begin{tabular}{|c|c|c|c|c|c|}
\hline No. & Materi & Normalitas & Homogenitas & t-test & Keputusan \\
\hline 1. & $\begin{array}{l}\text { Aritmatika Sosial } \\
\text { a. Eksperimen } \\
\text { b. Kontrol }\end{array}$ & $\begin{array}{l}\mathrm{L}=0,126<0,148 \\
\mathrm{~L}=0,136<0,148\end{array}$ & $\begin{array}{l}\chi^{2}=1,845< \\
3,841\end{array}$ & $\mathrm{t}=3,105>1,987$ & Ho ditolak \\
\hline 2. & $\begin{array}{l}\text { Perbandingan } \\
\text { a. Eksperimen } \\
\text { b. Kontrol }\end{array}$ & $\begin{array}{l}\mathrm{L}=0,126<0,148 \\
\mathrm{~L}=0,136<0,148\end{array}$ & $\begin{array}{l}\chi^{2}=1,845< \\
3,841\end{array}$ & $\mathrm{t}=6,247>1,987$ & Ho ditolak \\
\hline 3. & $\begin{array}{l}\text { Himpunan } \\
\text { a. Eksperimen } \\
\text { b. Kontrol }\end{array}$ & $\begin{array}{l}\mathrm{L}=0,126<0,148 \\
\mathrm{~L}=0,136<0,148\end{array}$ & $\begin{array}{l}\chi^{2}=1,845< \\
3,841\end{array}$ & $\mathrm{t}=2,045>1,987$ & Ho ditolak \\
\hline
\end{tabular}

Tabel 6. Hasil Analisis Reliabilitas Lembar Observasi Kemampuan Guru Mengelola Pembelajaran

\begin{tabular}{lllllllll}
\hline \multicolumn{1}{c}{ Pertemuan $($ RP) } & \multicolumn{1}{c}{$I$} & & \multicolumn{1}{c}{ II } & & \multicolumn{2}{c}{ Rata-rata } \\
\hline Frekuensi kecocokan $(A)$ dan & $A$ & $D$ & $A$ & $D$ & $A$ & $D$ & $A$ & $D$ \\
ketidakcocokan $(D)$ & 15 & 3 & 14 & 4 & 15 & 3 & 14,67 & 3,33 \\
Percentace of agreement $(R)$ & $83,33 \%$ & $77,78 \%$ & $83,33 \%$ & $81,48 \%$ \\
\multicolumn{1}{c}{ Reliabilitas } & Reliabel & Reliabel & Reliabel & Reliabel \\
\hline
\end{tabular}


Tabel 7. Hasil Analisis Reliabilitas Lembar Observasi Aktivitas Siswa

\begin{tabular}{rcccccccc}
\hline \multicolumn{1}{c}{ Pertemuan (RPP) } & \multicolumn{1}{c}{ I } & \multicolumn{2}{c}{ II } & & \multicolumn{2}{c}{ III } & \multicolumn{2}{c}{ Rata-rata } \\
\hline Frekuensi kecocokan (A) dan & A & D & A & D & A & D & A & D \\
ketidakcocokan (D) & 158 & 4 & 159 & 3 & 157 & 4 & 158 & 3,7 \\
Percentace of agreement (R) & 97,53 & $\%$ & $98,15 \%$ & $96,91 \%$ & $97,53 \%$ \\
\multicolumn{1}{c}{ Reliabilitas } & Reliabel & Reliabel & Reliabel & Reliabel \\
\hline
\end{tabular}

Diperoleh informasi bahwa percentasce of agreement $(R)$ lembar observasi kemampuan guru mengelola pembelajaran maupun lembar observasi aktivitas siswa, baik untuk setiap pertemuan maupun secara keseluruhan $>75 \%$, berarti lembar observasi kemampuan guru mengelola pembelajaran dan lembar observasi aktivitas siswa ini reliabel (Grinnel, 1998:160), sehingga dapat digunakan sebagai instrumen lembar observasi draft IV (draft final) tanpa revisi. Hal itu berarti pula bahwa data kemampuan guru mengelola pembelajaran dan data aktivitas siswa yang dikumpulkan menggunakan kedua lembar observasi dalam pelaksanaan uji coba perangkat pembelajaran ini valid.

Revisi perangkat pembelajaran selain perangkat tes hasil belajar siswa dari draft III menjadi draft IV didasarkan atas hasil analisis efektivitas pembelajaran dengan menggunakan lima indikator, yaitu indikator: (1) kemampuan guru mengelola pembelajaran; (2) aktivitas siswa; (3) respon guru; (4) respon dan minat siswa; dan (5) kesesuaian antara perkiraan waktu perencanaan dengan pelaksanaan di kelas, maka berikut ini dipaparkan kelima data hasil uji coba perangkat pembelajaran beserta hasil analisisnya masing-masing.

Hasil penilaian kemampuan guru mengelola pembelajaran untuk setiap pertemuan, tampak bahwa pada pertemuan pertama dan kedua beberapa kemampuan guru baru mencapai cukup baik, yaitu kemampuan guru dalam hal: (1) memotivasi siswa/mengkomunasikan tujuan pembelajaran; (2) menghubungkan pelajaran saat itu dengan sebelumnya; (3) menginformasikan langkah-langkah pembelajaran/ membahas PR; (4) menjelaskan soal/masalah kontekstual; (5) mengarahkan siswa untuk menemukan jawaban dan cara menjawab soal; (6) mengoptimalkan interaksi siswa dalam bekerja;
(7) memimpin diskusi kelas/menguasi kelas; (8) mengarahkan siswa untuk menemukan sendiri dan menarik kesimpulan; (9) mengarahkan siswa untuk membuat/menegaskan rangkuman materi pelajaran; dan (10) kemampuan mengelola waktu. Namun demikian, pada pertemuan berikutnya terdapat peningkatan menuju baik, bahkan sangat baik. Hal itu wajar mengingat pembelajaran itu masih relatif baru bagi guru mitra maupun bagi siswa. Bila ditinjau secara keseluruhan, rata-rata kemampuan guru mengelola pembelajaran matematika realistik dan antusias siswa adalah baik, kecuali kemampuan dalam hal menginformasikan langkah-langkah pembelajaran/membahas PR, memimpin diskusi kelas/ menguasi kelas, dan mengelola waktu baru mencapai cukup. Berarti, dari 17 komponen yang dinilai 14 komponen $(82,35 \%)$ baik dan tiga komponen $(17,65 \%)$ cukup.

Pembelajaran ini efektif ditinjau dari kemampuan guru mengelola pembelajaran. Namun demikian, beberapa kegiatan yang masih kurang baik atau cukup itu akan dipertimbangkan untuk merevisi perangkat pembelajaran yang dikembangkan, yaitu dengan memperjelas beberapa kegiatan pada RPP, khususnya pada beberapa kegiatan yang masih kurang baik atau cukup baik dilakukan guru tersebut.

Hasil pengamatan aktivitas siswa selama mengikuti proses pembelajaran ditinjau dari aktivitas siswa selama mengikuti proses pembelajaran secara keseluruhan dan untuk setiap pertemuan dapat dipaparkan sebagai berikut. (1) Pada pertemuan I, semua aktivitas siswa berada pada batas toleransi waktu ideal yang ditentukan. Pada pertemuan II dan IV terdapat satu aktivitas yang berada di bawah batas toleransi waktu ideal dan dua jenis aktivitas yang berada di atas batas toleransi waktu ideal yang ditetapkan. (2) Aktivitas yang kurang dari batas 
toleransi waktu ideal adalah mendengarkan/ memperhatikan guru dengan aktif, yaitu: 10,88 $\%$ (pertemuan II) dan $11,19 \%$ (pertemuan IV) dengan batas toleransi waktu ideal 15\%-25\% . (3) Aktivitas yang melebihi batas toleransi waktu ideal adalah membandingkan jawaban/ berdiskusi dalam kelompok belajar. Aktivitas membandingkan jawaban/ berdiskusi dalam kelompok belajar ini sebesar 15,2\% (pertemuan II), $13,96 \%$ (pertemuan III) dan $12,11 \%$ (pertemuan IV) dengan batas toleransi waktu ideal $2 \%$ $12 \%$. Berdasarkan paparan di atas, maka pembelajaran ini efektif ditinjau dari aktivitas siswa. Namun demikian, tiga jenis aktivitas mendengarkan/memperhatikan penjelasan guru dan membandingkan jawaban/ berdiskusi dalam kelompok belajar perlu digunakan sebagai pertimbangan untuk melakukan revisi terhadap RPP dan LKS. Revisi tersebut adalah dengan mengurangi beban pertanyaan pada LKS/ Buku Siswa dan merubah perkiraan waktu beberapa kegiatan pada RPP.

Angket respon guru terhadap perangkat dan pelaksanaan pembelajaran diberikan kepada tiga orang guru. Hasil angket menunjukkan bahwa semua guru memberikan respon yang positif atau sangat positif terhadap perangkat dan pelaksanaan pembelajaran matematika realistik pada materi Aljabar ini. Berdasarkan kriteria yang ditetapkan, pembelajaran ini efektif ditinjau dari respon guru.

Hasil angket respon siswa terhadap perangkat dan pelaksanaan pembelajaran menunjukkan bahwa dari 24 komponen perangkat dan pelaksanaan pembelajaran sebanyak 22 komponen $(91,67 \%)$ direspon positif oleh lebih dari $60 \%$ siswa dan dua komponen $(8,33 \%)$ direspon positif oleh kurang dari $60 \%$. Berdasarkan kriteria yang ditentukan, terlihat bahwa pembelajaran tersebut efektif ditinjau dari respon siswa. Komponen yang direspon positif oleh kurang dari $60 \%$ siswa adalah suasana pembelajaran. Dalam hal itu, justru mayoritas siswa, yakni $59,46 \%$ menyatakan tidak senang dan hanya $40,54 \%$ siswa yang menyatakan senang. Di samping itu, siswa yang menyatakan suasana pembelajaran itu baru hanya $54,05 \%$ dan yang menyatakan tidak baru $45,95 \%$.
Hal yang menyebabkan banyak siswa menyatakan tidak senang dengan suasana pembelajaran itu mungkin disebabkan dalam PMR ini dituntut siswa lebih aktif dalam belajar sejak awal pembelajaran dan guru tidak banyak memberi cara menyelesaikan masalah. Suasana pembelajaran seperti itu sangat berbeda dari kebiasaan mereka yang banyak pasif sebagai pendengar dan selalu dijelaskan serta diberi contoh pembahasan soal. Atau karena biasanya kebanyakan siswa kurang suka bila disuruh maju ke depan kelas untuk mengerjakan soal atau mempresentasikan jawaban, sedangkan dalam PMR kegiatan ini merupakan kegitan inti pembelajaran. Hal yang menyebabkan banyak siswa menyatakan bahwa suasana pembelajaran di kelas itu tidak baru, kemungkinan adalah karena PMR masih relatif baru bagi guru mitra sehingga masih agak sulit untuk menciptakan suasana pembelajaran yang benar-benar sesuai dengan tuntutan PMR yang tampak jelas berbeda dari biasanya.

Berdasarkan pengamatan selama uji coba perangkat pembelajaran tentang kesesuian antara perkiraan waktu pada RPP dan LKS dengan pelaksanaan di lapangan, ternyata terdapat perkiraan waktu pada RPP yang masih kurang tepat dengan pelaksanaan dan terdapat satu kegiatan pada RPP yang sulit dilaksanakan. Beberapa kegiatan yang kurang tepat antara perkiraan waktu pada RPP dengan pelaksanaan antara lain kegiatan: (1) memotivasi siswa; (2) mengingatkan materi prasyarat; (3) menyelesaikan masalah; dan (4) membandingkan jawaban masing-masing kegiatan terdapat selisih antara dua sampai tiga menit. Satu kegiatan yang sulit dilaksanakan di lapangan adalah penilaian proses, meskipun hanya dilakukan secara tidak formal. Hal itu mengingat terlalu banyaknya siswa di kelas dan guru lebih memfokuskan pemberian bimbingan terbatas secara individual pada saat siswa mengerjakan LKS dan soal latihan.

Berdasarkan analisis deskreptif terhadap: (1) kemampuan guru mengelola pembelajaran; (2) aktivitas siswa; (3) respon guru; (4) respon dan minat siswa; dan (5) kesesuaian antara perkiraan waktu perencanaan dengan pelaksanaan di kelas menunjukkan bahwa pembelajaran 
selama uji coba di kelas VIIG SMP Negeri 2 Sukoharjo menggunakan perangkat PMR pada materi Aljabar efektif. RPP, Buku Siswa, LKS dan Buku Petunjuk Guru draft III baik atau valid, meskipun untuk menjadikannya sebagai draft IV (draft final) masih diperlukan beberapa revisi.

Beberapa revisi tersebut secara garis besar dilakukan sebagai berikut. (1) Menyesuaikan perkiraan waktu beberapa kegiatan pada RPP dengan pelaksanaan di lapangan. (2) Memperjelas beberapa kegiatan pada RPP. (3) Menyesuaikan halaman buku siswa, petunjuk dan alternatif jawaban pada Buku Petunjuk Guru, dengan revisi pada Buku Siswa dan LKS serta dengan menambahkan alternatif penyelesaian yang dilakukan siswa di lapangan. Revisi perangkat tes hasil belajar siswa dari draft III menjadi draft IV (draft final) dalam penelitian ini adalah didasarkan dari hasil analisis validitas dan reliabilitas perangkat tes. Berdasarkan hasil analisis tes, secara keseluruhan perangkat tes ini cukup dapat mengukur dengan tepat tujuan pembelajaran yang ditetapkan. Hasil analisis reliabilitas perangkat tes, ternyata memiliki reliabilitas sangat tinggi, berarti perangkat tes ini memiliki keajegan sangat tinggi untuk digunakan sebagai alat penilaian hasil belajar siswa.

Berdasarkan paparan di atas, diputuskan bahwa perangkat tes hasil belajar siswa draft III untuk dijadikan draft IV (draft final), masih memerlukan revisi. Revisi tersebut secara garis besar dilakukan dengan cara: (1) mengurangi banyak butir soal yang berfungsi untuk mengukur KD yang sama; dan (2) merevisi kisi-kisi tes, alternatif jawaban siswa dan pedoman pemberian skor sesuai dengan revisi pada butir soal tes.

Penerapan pembelajaran dengan pendekatan matematika realistik juga pernah dilakukan oleh Syahputra (2013) di Medan, yaitu berkaitan dengan kemampuan spasial. Hasil penelitian menyimpulkan bahwa siswa dibelajarkan dengan pendekatan matematika realistik lebih baik daripada kemampuan spasial siswa yang dibelajarkan dengan pendekatan konvensional.
Penelitian lain yang bertujuan meneliti perbedaan hasil belajar sebagai akibat penerapan model pembelajaran tertentu adalah yang dilakukan oleh Redhana (2014), yaitu yang meneliti efek penerapan pembelajaran model seminar Socrates dan model pembelajaran langsung. Hasil penelitian menunjukkan bahwa terdapat perbedaan yang signifikan hasil belajar antara siswa yang belajar dengan model pembelajaran seminar Socrates dan siswa yang belajar dengan model pembelajaran langsung. Siswa yang belajar dengan model pembelajaran seminar Socrates menunjukkan hasil lebih tinggi daripada siswa yang belajar dengan model pembelajaran langsung.

\section{PENUTUP}

Berdasarkan analisis data dan diskusi hasil penelitian melalui prosedur pengembangan perangkat pembelajaran Model 4-D (Four DModel) yang dimodifikasi hanya sampai pada tahap pengembangan (develope), dapat disimpulkan hal-hal seperti berikut. (1) Perangkat pembelajaran dengan pendekatan Pembelajaran Matematika Realistik di Sekolah Menengah Pertama telah teruji secara teoretis. (2) Perangkat pembelajaran dengan pendekatan Pembelajaran Matematika Realistik di Sekolah Menengah Pertama telah dinilai ahli dengan nilai 3 atau dapat digunakan dengan sedikit revisi. (3) Rencana Pelaksanaan Pembelajaran tertentu telah diuji terbatas keterbacaan dan disimulasikan. (4) Perangkat pembelajaran dan instrumen penelitian telah diuji coba terbatas.

Hasil pengembangan instrumen penelitian pembelajaran matematika realistik pada materi Aljabardi kelas VII SMP ini berupa: (1) Lembar Penilaian Validator terhadap Perangkat Pembelajaran dan Instrumen Penelitian; (2) Lembar Angket Respon Guru terhadap Perangkat dan Pelaksanaan Pembelajaran; (3) Lembar Angket Respon Siswa terhadap Perangkat dan Pelaksanaan Pembelajaran; (4) Lembar Observasi Kemampuan Guru Mengelola Pembelajaran; dan (5) Lembar Observasi Aktivitas Siswa Selama Mengikuti Proses Pembelajaran. Semua instrumen penelitian tersebut setelah dilakukan: validasi ahli dan direvisi berdasarkan: penilaian, 
koreksi dan saran perbaikan para ahli adalah baik atau valid. Khusus untuk instrumen Lembar Observasi Kemampuan Guru Mengelola Pembelajaran dan Lembar Observasi Aktivitas Siswa Selama Mengikuti Proses Pembelajaran, di samping baik atau valid juga reliabel berdasarkan kecocokan dua pengamat. Hasil pengembangan perangkat pembelajaran matematika realistik pada materi Aljabar di kelas VII SMP ini, berupa:(1) Rencana Pelaksanaan Pembelajaran (RPP); (2) Buku Siswa; (3) Lembar Kerja Siswa (LKS); (4) Buku Petunjuk Guru (BPG) dan (5) Perangkat Tes Hasil Belajar Siswa. Semua perangkat pembelajaran tersebut, setelah: (1) divalidasi ahli; (2) direvisi berdasarkan: penilaian, koreksi dan saran perbaikan para ahli; (3) dilakukan uji keterbacaan dan simulasi RPP tertentu; (4) direvisi berdasarkan analisis data hasil uji keterbacaan dan simulasi RPP tertentu; (5) dilakukan uji coba di kelas; dan (6) direvisi berdasarkan analisis data hasil uji coba, adalah baik atau valid.

\section{UCAPAN TERIMA KASIH}

Penulis mengucapkan terima kasih kepada Direktorat Jenderal Pendidikan Tinggi yang telah menfasilitasi pelaksanaan penelitian ini dalam bentuk dana hibah penelitian dosen pemula. Semoga penelitian ini memberikan manfaat, khususnya bagi dunia pendidikan.

\section{DAFTAR PUSTAKA}

Marpaung, Y. 2001. "Pedekatan Realistik dalam Pembelajaran Matematika". Makalah Disajikan pada Seminar Nasional "Pendidikan Matematika Realistik" di Universitas Sanata Dharma Yogyakarta. Tanggal, 14 - 15 Nopember 2001.

Redhana, I Wayan. 2014. "Pengaruh Model Pembelajaran Seminar Socrates terhadap Hasil Belajar Siswa”. Cakrawala Pendidikan, Th XXXIII, No.1, hlm. 27-38.

Soedjadi, R. 1999. Kiat Pendidikan Matematika di Indonesia. Jakarta: Dirjen Dikti Depdikbud.

Soedjadi, R. 2001. "Pemanfaatan Realitas dan lingkungan dalam Pembelajaran Matematika”. Makalah Disajikan pada Seminar Nasional Realistics Mathematic Education (RME) di UNESA Surabaya, 24 Pebruari 2001.

Syahputra, Edi. 2013. "Peningkatan Kemampuan Spasial Siswa melalui Penerapan Pembelajaran Matematika Realistik". Cakrawala Pendidikan, Th XXXII, No.3, hlm. 353-364.

Thiagarajan, S., Semmel, D.S., dan Semmel, M.I. 1974. Instructional Development for Teacher of Exceptional Children. Bloomington: Indiana University. 